\title{
GENERALIZED OSTROWSKI-TYPE INEQUALITIES FOR $s$-CONVEX FUNCTIONS ON THE COORDINATES VIA FRACTIONAL INTEGRALS
}

\section{Seth KeRmausuor}

\begin{abstract}
We established some new fractional integral inequalities of Ostrowski-type for functions of two independent variables whose second order mixed partial derivatives in absolute value to some powers are $s$-convex on the coordinates. These results are obtained by using generalized Katugampola-type fractional integrals for functions of two independent variables. Our results generalizes some results in the literature.
\end{abstract}

Mathematics subject classification (2010): 26A33, 26A51, 26D10, 26D15.

Keywords and phrases: Ostrowski inequality, convex functions on the coordinates, $s$-convex functions on the coordinates, Katugampola fractional integrals, Riemann-Liouville fractional integrals, Hölder's inequality, power mean inequality.

\section{REFERENCES}

[1] M. Alomari AND M. Darus, The Hadamard's inequality for s-convex function of 2-variables on the co-ordinates, Int. J. Math. Anal. 2, 13 (2008), 629-638.

[2] M. Alomari, M. Darus, S. S. Dragomir And P. Cerone, Ostrowski type inequalities for the functions whose derivative are s-convex in second sense, Appl. Math. Lett. 23, (2010), 1071-1076.

[3] G. A. Anastassiou, Ostrowski type inequalities, Proc. Amer. Math. Soc. 123, (1995), 3775-3781.

[4] H. Chen and U. N. Katugampola, Hermite-Hadamard and Hermite-Hadamard-Fejér type inequalities for generalized fractional integrals, J. Math. Anal. Appl. 446, (2) (2017), 1274-1291.

[5] S. S. DRAGOMIR, On Hadamard's inequality for convex functions on the co-ordinates in a rectangle from the plane, Taiwanese J. Math. 5, (2001), 775-788.

[6] S. S. DRAGOMIR, A generalization of Ostrowski integral inequality for mappings whose derivatives belong to $L_{1}[a, b]$ and applications in numerical integration, J. Comput. Anal. Appl. 3, (2001), 343360 .

[7] S. S. DRAGOMIR, A generalization of the Ostrowski integral inequality for mappings whose derivatives belong to $L_{p}[a, b]$ and applications in numerical integration, J. Math. Anal. Appl. 255, (2001), 605-626.

[8] S. S. DRAGOMIR AND S. WANG, A new inequality of Ostrowski's type in $L_{1}$-norm and applications to some special means and to some numerical quadrature rules, Tamkang J. Math. 28, (1997), 239244.

[9] S. S. Dragomir AND S. WANG, A new inequality of Ostrowski's type in $L_{p}$-norm, Indian J. Math. 40, (1998), 299-304.

[10] G. FARID AND M. USMAN, Ostrowski type $k$-fractional integral inequalities for MT-convex and $h$ convex functions, Nonlinear Funct. Anal. Appl. 22, (2017), 627-639.

[11] G. FARID, U. N. KatUgampola AND M. Usman, Ostrowski-type fractional integral inequalities for mappings whose derivatives are h-convex via Katugampola fractional integrals, Stud. Univ. Babeş-Bolyai Math. 63, (2018), 465-474.

[12] G. Farid, U. N. Katugampola And M. Usman, Ostrowski type fractional integral inequalities for s-Godunova-Levin functions via Katugampola fractional integrals, Open J. Math. Sci. 1, (2017), 97-110.

[13] H. Hudzik And L. Maligranda, Some remarks on s-convex functions, Aequationes Math. 48, 1 (1994), 100-111. 
[14] U.N. Katugampola, New approach to a generalized fractional integral, Appl. Math. Comput. 218, (3) (2011), 860-865.

[15] U. N. KatUgampola, A new approach to generalized fractional derivatives, Bull. Math. Anal. Appl. 6, (4) (2014), 1-15.

[16] S. KeRMAUSUOR, Ostrowski type inequalities for functions whose derivatives are strongly $(\alpha, m)$ convex via k-Riemann-Liouville fractional integrals, Stud. Univ. Babeş-Bolyai Math. 64, 1 (2019), $25-34$.

[17] S. Kermausuor, Generalized Ostrowski-type inequalities involving second derivatives via the Katugampola fractional integrals, J. Nonlinear Sci. Appl. 12 (2019), 509-522.

[18] S. Kermausuor, Simpson's type inequalities via the Katugampola fractional integrals for s-convex functions, Kragujevac J. Math. 45, 5 (2021), 709-720.

[19] S. Kermausuor AND E. R. NwaEZe, Some new inequalities involving the Katugampola fractional integrals for strongly $\eta$-convex functions, Tbilisi Math. J. 12, 1 (2019), 117-130.

[20] S. Kermausuor, E. R. Nwaeze And A. M. TAmeru, New Integral Inequalities via the Katugampola Fractional Integrals for Functions Whose Second Derivatives Are Strongly $\eta$-Convex, Mathematics 7, 2 (2019), 183.

[21] M. A. Latif, S. S. Dragomir And A. E. Matouk, New inequalities of Ostrowski type for coordinated s-convex functions via fractional integrals, J. Fract. Calc. Appl. 4, 1 (2013), 22-36.

[22] M. A. LATIF AND S. HuSSAIN, New inequalities of Ostrowski type for co-ordinated convex functions via fractional integrals, J. Fract. Calc. Appl. 2, 9 (2012), 1-15.

[23] A. M. OstrowsKI, Über die Absolutabweichung einer differentiebaren Funktion von ihrem Integralmitelwert, Comment. Math. Helv. 10, (1938), 226-227.

[24] M. Z. SARIKAYA, On the Hermite-Hadamard-type inequalities for co-ordinated convex function via fractional integrals, Integral Transforms Spec. Funct. 25, 2 (2014), 134-147.

[25] E. SET, New inequalities of Ostrowski type for mappings whose derivatives are s-convex in the second sense via fractional integrals, Comput. Math. Appl. 63, (2012), 1147-1154. 